\title{
Validation and Application of a New Reversed Phase HPLC Method for In Vitro Dissolution Studies of Rabeprazole Sodium in Delayed-Release Tablets
}

\author{
Md. Saddam Nawaz \\ Quality Assurance Department, ACI Ltd., Narayanganj 1400, Bangladesh \\ Correspondence should be addressed to Md. Saddam Nawaz; nawazdu@gmail.com
}

Received 21 May 2013; Revised 18 July 2013; Accepted 19 July 2013

Academic Editor: Josep Esteve-Romero

Copyright (c) 2013 Md. Saddam Nawaz. This is an open access article distributed under the Creative Commons Attribution License, which permits unrestricted use, distribution, and reproduction in any medium, provided the original work is properly cited.

\begin{abstract}
The purpose of this study was to develop and validate a new reversed phase high performance liquid chromatographic (RP-HPLC) method to quantify in vitro dissolution assay of rabeprazole sodium in pharmaceutical tablet dosage form. Method development was performed on $\mathrm{C} 18,100 \times 4.6 \mathrm{~mm} \mathrm{ID}$, and $10 \mu \mathrm{m}$ particle size column, and injection volume was $20 \mu \mathrm{L}$ using a diode array detector (DAD) to monitor the detection at $280 \mathrm{~nm}$. The mobile phase consisted of buffer: acetonitrile at a ratio of $60: 40(\mathrm{v} / \mathrm{v})$, and the flow rate was maintained at $1.0 \mathrm{~mL} / \mathrm{min}$. The method was validated in terms of suitability, linearity, specificity, accuracy, precision, stability, and sensitivity. Linearity was observed over the range of concentration $0.05-12.0 \mu \mathrm{g} / \mathrm{mL}$, and the correlation coefficient was found excellent $>0.999$. The method was specific with respect to rabeprazole sodium, and the peak purity was found 99.99\%. The method was precise and had relative standard deviations (RSD) less than 2\%. Accuracy was found in the range of 99.9 to $101.9 \%$. The method was robust in different variable conditions and reproducible. This proposed fast, reliable, cost-effective method can be used as quality control tool for the estimation of rabeprazole sodium in routine dissolution test analysis.
\end{abstract}

\section{Introduction}

Since 1980s, proton pump inhibitors (PPIs) are the most potent inhibitors of gastric acid secretion and effective for treating all gastric acid-related disorders, including gastroesophageal reflux disease (GERD), peptic ulcer disease (PUD), and nonsteroidal anti-inflammatory drug- (NSAID-) induced gastropathy. Rabeprazole sodium (RPS) belongs to a class of PPIs that suppresses gastric acid secretion by specific inhibition of the enzyme system of hydrogen/potassium adenosine triphosphatase $\left(\mathrm{H}^{+} / \mathrm{K}^{+}\right.$ATPase $)$at the secretory surface of the gastric parietal cell. In contrast to the other PPIs, RPS is the most potent acid secretion inhibitor during first day of dosing [1]. RPS hinders gastric acid secretion up to the final steps [2]. It may also be used with an antibiotic to prevent gastric ulcer caused by infection Helicobacter pylori (H. pylori). Rabeprazole sodium is chemically 2-[(4)3methoxypropoxy-3-methyl-2-pyridinyl sulphinyl] 1-H benzimidazole sodium salt (Figure 1). It has an empirical formula of $\mathrm{C}_{18} \mathrm{H}_{20} \mathrm{~N}_{3} \mathrm{NaO}_{3} \mathrm{~S}$, molecular weight of 381.43 , and halflife of 1-2 hour. RPS is a white to yellowish crystalline solid and soluble in water, methanol, and acetonitrile but insoluble in ether and n-hexane. RPS is a substituted benzimidazole which stability is depending on pH. Like most other PPIs, it is rapidly degraded in acid medium to yield two main products, the sulfenamide and the benzimidazole sulphide, but it is more stable under basic condition.

Rabeprazole sodium is not available yet any of the pharmacopoeias. Methods that have been reported for the determination of RPS include HPLC [3-11], thin layer chromatography (TLC) [12], HPTLC [13, 14], UV spectrophotometry [15-17], LCMS [18], and voltametry [19]. And some methods have also been published for the quantitative analysis of RPS in combination formulations with other drugs [20,21].

Although a number of articles had been published for the HPLC assay of RPS, they were mostly in combination with antiemetic drug domperidone or cholinergic drug itopride. There is no solution stability representing validated RP-HPLC 


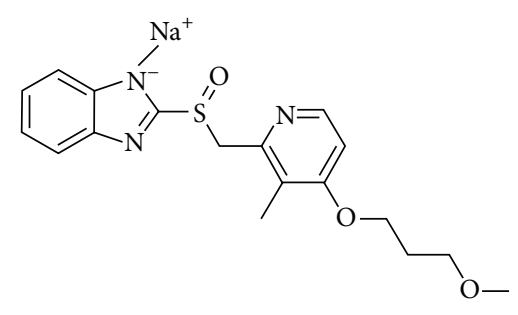

FIGURE 1: Chemical structure of rabeprazole sodium.

method so far published to investigate dissolution assay of RPS. The aim of the present work was to develop a simple, precise, fast, and solution stability demonstrating RP-HPLC method for the determination of RPS in delayed-release (DR) tablet dosage form during in vitro dissolution studies. The authentication of the applicability of this developed method was validated according to the International Conference on Harmonization (ICH) Q2 (R1) and the United States Pharmacopeia (USP) [22, 23].

\section{Experimental}

2.1. Reagents and Chemicals. The RPS standard and API were obtained from Metrochem API Private Limited, Hyderabad, India. AcipHex (Eisai Inc., NJ, USA) tablets (each DR tablet contains $20 \mathrm{mg}$ rabeprazole sodium) were purchased commercially from the market. Acetonitrile HPLC grade (Scharlau, Spain), methanol HPLC grade (Scharlau, Spain), disodium hydrogen phosphate AR grade (Scharlau, Spain), phosphoric acid AR grade (Merck; Germany), hydrochloric acid (Scharlau, Spain) and Tris (hydroxymethyl) aminomethane AR grade (Scharlau, Spain) were used for analytical purposes. Ultrapure water was used to prepare the mobile phase, diluting solution and dissolution medium. Ultra pure water was prepared by using Labconco WaterPro PS (USA) purification system.

\subsection{Instrumentation and Chromatographic Condition. Chro-} matographic separation was achieved by using Shimadzu (Japan) prominence LC-20AD high performance liquid chromatography, equipped with degasser PGU-20A 5, variable wavelength programmable diode array detector SPD-M20A, autosampler SIL-20 AC HT, and column oven CTO-10 A5 VP. The data was recorded using LC LabSolution software (Japan). ProntoSIL SC, C 18-ace-EPS, $100 \times 4.6 \mathrm{~mm} \mathrm{ID,} \mathrm{and}$ $10 \mu \mathrm{m}$ particle size column (Bischoff, Germany), was used as the stationary phase. The column oven temperature was kept at ambient condition and the mobile phase flow rate was maintained at $1.0 \mathrm{~mL} / \mathrm{min}$. The detection was monitored at $280 \mathrm{~nm}$. The injection volume was $20 \mu \mathrm{L}$, and the run time was $4 \mathrm{~min}$ for each injection. Other instruments such as dissolution apparatus (Logan UDT-804-12, USA), pH meter (Jenway 3510, UK), electronic weighing balance (MettlerToledo, Switzerland) and ultrasonic bath (Clifton, UK) were also used.
Dionex ultimate 3000 series (USA) HPLC and Chromeleon software (USA) were used during ruggedness study.

2.2.1. Mobile Phase. To prepare buffer solution for mobile phase, $1.42 \mathrm{~g}$ of disodium hydrogen phosphate was dissolved in $800 \mathrm{~mL}$ of ultra pure water. Then the solution $\mathrm{pH}$ was adjusted to $7.6 \pm 0.1$ with orthophosphoric acid and volume up to $1000 \mathrm{~mL}$ with ultra pure water.

Finally a mixture of above prepared buffer and acetonitrile $(\mathrm{ACN})$ at a ratio of $60: 40(\mathrm{v} / \mathrm{v})$ was used as mobile phase. The prepared buffer and acetonitrile $(\mathrm{ACN})$ were sonicated for 5 min using ultrasonic bath and filtered using $0.2 \mu \mathrm{m}$ membrane filters before used.

2.2.2. Diluting Solution. Diluent $A$ : A mixture of $0.1 \mathrm{~N} \mathrm{HCl}$ and $0.6 \mathrm{M}$ Tris buffer at a ratio of $7: 3$ was prepared and the final $\mathrm{pH}$ was adjusted to $8.0 \pm 0.5$ with $2 \mathrm{~N} \mathrm{HCl}$ or $2 \mathrm{~N} \mathrm{NaOH}$.

Diluent B: Methanol.

2.2.3. Standard Preparation. $50.0 \mathrm{mg}$ RPS working standard was accurately weighed and transferred into a clean and dry $100 \mathrm{~mL}$ standard volumetric flask and fully dissolved with the diluent $A$ and finally volume up to the mark with the same solvent.

After which, $2 \mathrm{~mL}$ aliquot of the above solution was transferred instantaneously into another dry $100 \mathrm{~mL}$ standard volumetric flask and diluted to the mark with the diluent $B$ to make a concentration of $10 \mu \mathrm{g} / \mathrm{mL}$. Finally the solution was filtered through $0.45 \mu \mathrm{m}$ PTFE (polytetrafluoroethylene) disk filter during transfer to the amber vial.

\subsubsection{Dissolution Test Conditions and Analytical Procedure.} Twelve-vessel dissolution unit was used to analysis of test samples by using this developed method. The dissolution test followed the procedure predetermined by US FDA (United States Food and Drug Administration) using USP apparatus 2 (paddles) [24]. The paddle speed was $100 \mathrm{rpm}$, and the temperature of the dissolution medium was maintained $37.0 \pm 0.5^{\circ} \mathrm{C}$ by covering the vessel. Dissolution medium was prepared according to the US FDA recommendation. The US FDA recommended dissolution test conditions, at acid stage was; $700 \mathrm{~mL}$ of $0.1 \mathrm{~N} \mathrm{HCl}$ for $120 \mathrm{~min}$ and at buffer stage, $300 \mathrm{~mL}$ of $0.6 \mathrm{M}$ Tris buffer was added into the acid medium with necessary adjusting of $\mathrm{pH}$ to 8.0 with $2 \mathrm{~N} \mathrm{HCl}$ or $2 \mathrm{~N}$ $\mathrm{NaOH}$ and the dissolution test was continued for $45 \mathrm{~min}$.

After two hours, $5 \mathrm{~mL}$ samples were collected for assay analysis of RPS from acid stage and immediately diluted to $10 \mathrm{~mL}$ with the $5 \mathrm{~mL}$ of diluent $B$ and $5 \mathrm{~mL}$ samples were also withdrawn from buffer stage at intervals (10, 20, 30 and $45 \mathrm{~min}$ ) for assay analysis of RPS and immediately diluted to $10 \mathrm{~mL}$ with the $5 \mathrm{~mL}$ of diluent $B$. The samples were filtered through $0.45 \mu \mathrm{m}$ PTFE disk filter and transferred to the amber vial. The first $2 \mathrm{~mL}$ of the sample that obtained each time during filtration was discarded in order to clean out the filter. 


\subsection{Method Validation Parameters}

2.3.1. System Suitability. To evaluate system suitability of the method, six replicate injections of standard RPS solution were injected, and the percent relative standard deviation (\%RSD) values of the parameters such as repeatability, tailing factor, and retention time were calculated in each case.

2.3.2. Linearity. Three replicated, eight different concentration levels test solutions from 0.5 to $120 \%$ of analyte concentration $(0.05,0.1,1.0,2.5,5.0,8.0,10.0$, and $12.0 \mu \mathrm{g} / \mathrm{mL})$ were prepared from RPS standard. The linearity was evaluated by mean of replicated peak area versus concentration, which was calculated by linear regression analysis.

2.3.3. Specificity. The specificity of the developed RP-HPLC method was investigated by chromatographic analysis of commercially available placebo samples of AcipHex tablets in the usual concentration of excipients. To check the noninterference of placebo, placebo ingredients of the AcipHex tablet formulation but not including RPS were transferred to dissolution vessels containing $1000 \mathrm{~mL}$ of diluent $A$ and stirred at $37^{\circ} \mathrm{C}$ for $120 \mathrm{~min}$ at $100 \mathrm{rpm}$ using USP paddle apparatus. While aliquots of the solution was filtered through Whatman number 42 filter paper and pipetted $5 \mathrm{~mL}$ into a $10 \mathrm{~mL}$ volumetric flask and volume up to the mark with diluent $B$, the $3 \mathrm{D}$ image of peak and the peak purity tool was used to evaluate the peak purity of the dissolution test solution.

2.3.4. Accuracy. Accuracy parameter was determined by the recovery test, which consisted of adding and dissolving known amounts of RPS into the placebo sample solutions with followed by required dilution in methanol. Placebo solution was prepared by dissolving placebo samples in $1000 \mathrm{~mL}$ of diluent $A$ at $37^{\circ} \mathrm{C}$, and after which, filtered through Whatman number 42 filter paper. This test was conducted by four different concentrations $(0,50,100$, and 120\%), that is, $0,5.0,10.0$, and $12.0 \mu \mathrm{g} / \mathrm{mL}$ of test sample in three replicate sample preparations and the percent recoveries (mean \pm $\%$ RSD of three replicates) of RPS in drug-placebo form were calculated.

2.3.5. Precision. Precision of the method was determined by repeatability (intraday precision) and intermediate precision (interday precision) of RPS standard solutions. Intra-day precision was determined in six replicates of RPS standard solution $(10 \mu \mathrm{g} / \mathrm{mL})$ on the same day. The intermediate precision of the method was also evaluated on different days with different analyst using the same column and instrument in the same laboratory. The results were expressed as \%RSD of the measurements.

2.3.6. Stability of Solution. The solution stability was tested by allowing the prepared dissolution assay tested sample (sample was withdrawn at buffer stage) with to stand exposed to room light and ambient room temperature for 6 hours. The sample was injected every hour, and different percentage was compared to the value of initially prepared original sample solutions.

2.3.7. Sensitivity. For sensitivity study the limit of detection (LOD) and limit of quantitation (LOQ) were estimated by determination of signal-noise ratios of $3.3: 1$ and $10: 1$, respectively, by injecting series of dilute solution with known concentrations.

2.3.8. Robustness. To determine the robustness of the current method, the effect of flow rate was studied at 0.9 and $1.1 \mathrm{~mL} / \mathrm{min}$ instead of $1.0 \mathrm{~mL} / \mathrm{min}$. The effect of mobile phase composition was assessed at (buffer: $\mathrm{ACN}=59: 41, \mathrm{v} / \mathrm{v}$ ) and (buffer: $\mathrm{ACN}=61: 39, \mathrm{v} / \mathrm{v}$ ) instead of (buffer : $\mathrm{ACN}=60: 40$, $\mathrm{v} / \mathrm{v})$. The effect of wavelength change was studied at $279 \mathrm{~nm}$ and $282 \mathrm{~nm}$ instead of $280 \mathrm{~nm}$.

2.3.9. Ruggedness. Ruggedness of the current method was determined by analyzing six dissolution assay sample solutions of AcipHex tablet by different Instrument (Dionex ultimate 3000 series HPLC), different column of the same brand (ProntoSIL SC, C 18-ace-EPS, $100 \times 4.6 \mathrm{~mm} \mathrm{ID} \mathrm{and}$ $10 \mu \mathrm{m}$ particle size) but in the different laboratory to check the reproducibility of the test result.

\section{Results and Discussion}

3.1. Method Optimization. To avoid the degradation of RPS the buffer solution $\mathrm{pH}$ of mobile phase was adjusted at 7.6, as RPS, is most stable at higher $\mathrm{pH}$. The mobile phase was optimized in the ratio of buffer : ACN $(60: 40 \mathrm{v} / \mathrm{v})$ with a flow rate $1.0 \mathrm{~mL} / \mathrm{min}$. Chromatographic separation was achieved at $280 \mathrm{~nm}$, where the linearity of the proposed method was found more satisfactory rather than RPS maximum UV absorbance $(\lambda \max )$ at $285 \mathrm{~nm}$. Regular commercial C 18 column of ProntoSIL SC, C 18-ace-EPS, $100 \times 4.6 \mathrm{~mm}$ ID containing particle size of 3,5 , and $10 \mu \mathrm{m}$ was tried. The peak was sharp and tailing factor was acceptable for the column of 3, 5 and $10 \mu \mathrm{m}$ size particles but $10 \mu \mathrm{m}$ particle size column life was found interestingly more stable at this high $\mathrm{pH}$. The inject volume was chosen only $20 \mu \mathrm{L}$, and the total run time was fixed at $4 \mathrm{~min}$ as further any peak of excipients, or blank was not observed.

While developing the method, stability of RPS into US FDA recommended Tris buffer ( $\mathrm{pH}$ 8.0) solution was taken into account sincerely. RPS was found less stable in tris buffer medium. To enhance stability of RPS, an instant dilution was performed into the organic solvent (methanol), all through the preparation of standard and sample. US FDA suggests additional $0.5 \mathrm{~N} \mathrm{NaOH}$ into the dissolution medium to stabilize the sample. Additional $\mathrm{NaOH}$ may increase the $\mathrm{pH}$ of tris buffer medium, this part was avoided in this study to maintain the $\mathrm{pH}$ of dissolution medium at 8.0, and HPLC column life is also very shorter at high $\mathrm{pH}$. Moreover, according to USP and US FDA, $\mathrm{pH}$ of the dissolution medium as buffered aqueous solution usually is 4 to 8 , and a higher $\mathrm{pH}$ should be justified, and in general, should not exceed $\mathrm{pH} 8.0$ $[23,25]$. 


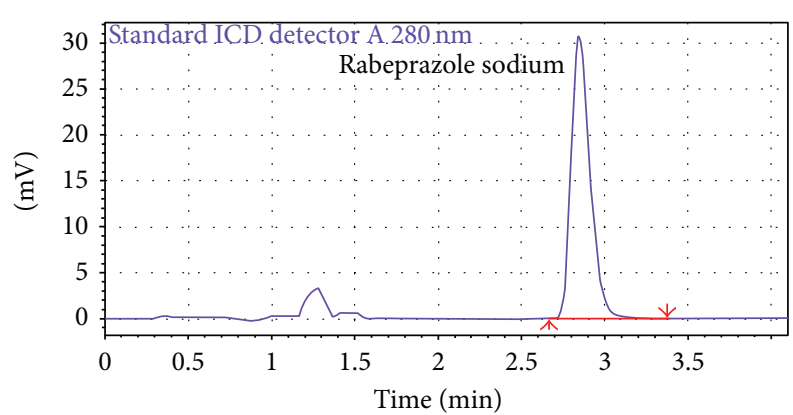

(a)

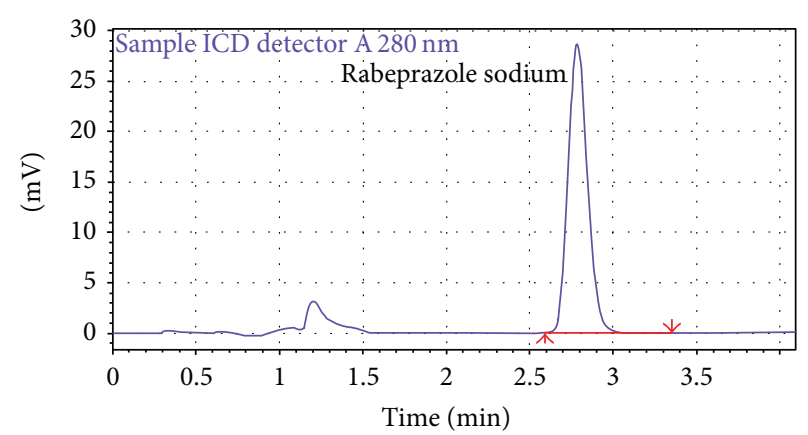

(b)

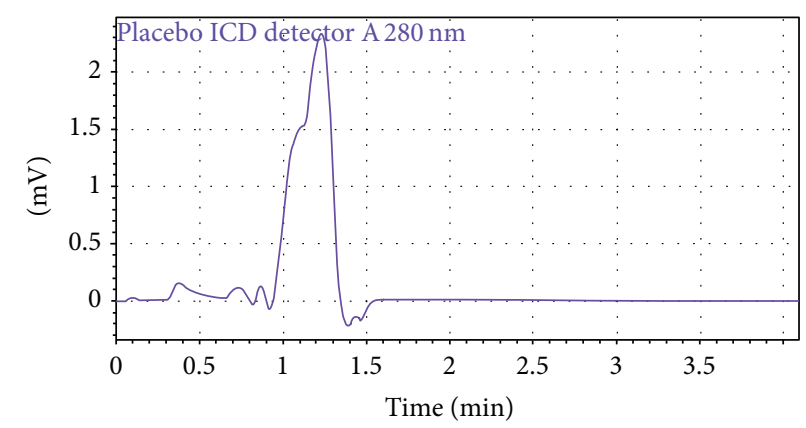

(c)

FIGURE 2: RP-HPLC chromatogram of (a) standard, (b) assay sample, and (c) placebo sample of rabeprazole sodium.

TABLE 1: Chromatographic characteristics of system suitability study.

\begin{tabular}{lc}
\hline Parameters & Value (mean $\pm \%$ RSD), $n=6$ \\
\hline Peak area & $206343 \pm 0.2$ \\
Tailing factors & $1.1 \pm 1.5$ \\
Retention time $(\mathrm{min})$ & $2.7 \pm 0.1$ \\
\hline
\end{tabular}

\subsection{Method Validation}

3.2.1. System Suitability. The results (mean \pm RSD of six replicates) of the chromatographic parameters of the proposed method indicate the good performance of the system (Table 1).

3.2.2. Linearity. The linearity of the calibration plot for the method was obtained over the calibration ranges tested, that is, $0.05-12 \mu \mathrm{g} / \mathrm{mL}$ (Table 2), and the correlation coefficient obtained was $>0.999$, thus indicating high degree of correlation between peak areas and concentrations of the analyte. The regression equation for RPS was $y=20235 x-432\left(R^{2}=\right.$ $0.9999)$.

3.2.3. Specificity. The chromatograms of blank, placebo, test sample, and standard, used to justify the specificity of target analyte. The method was specific since none of peaks did not appear at the retention time of RPS (Figure 2) and in every case the peak purity was $99.99 \%$ and no impurity peaks were detected (Figure 3).
3.2.4. Accuracy. The overall results of percent recoveries (mean \pm \%RSD) of drug-placebo solutions ranged from 99.9 to 101.9 are indicating good accuracy of the proposed RPHPLC method (Table 3). The results also revealed that there was no interference of excipients.

3.2.5. Precision. The values of $\%$ RSD for intra-day and interday variation were found very well and within $2 \%$ limit, indicating that the current method is precise (Table 4).

3.2.6. Stability of Solution. In the stability study, the peak area of RPS in dissolution assay sample solutions decreased insignificantly at four hour which is more than $2.0 \%$ from initial. This indicates that sample solutions were stable for at least 3 hours, which was absolutely sufficient to complete the analytical procedure (Table 5).

3.2.7. Sensitivity. The LOD and LOQ by the proposed method were found for RPS that was $0.01 \mu \mathrm{g} / \mathrm{mL}$ and $0.03 \mu \mathrm{g} / \mathrm{mL}$, respectively.

3.2.8. Robustness. The effects of robustness study under different altered conditions of this proposed method were satisfactory. The mean and \%RSD of standard and analyzed sample indicate that the current method is robust (Table 6).

3.2.9. Ruggedness. The results (\% of recovery \pm RSD) of six assay samples are indicating the ruggedness of the current method (Figure 4, Table 7). 
TABLE 2: Linearity of the method.

\begin{tabular}{|c|c|c|c|c|}
\hline Number of preparation & Sample conc. $\%$ & Sample conc. $(\mu \mathrm{g} / \mathrm{mL})$ & Peak area & Mean of peak area \\
\hline & & & 1080 & \\
\hline \multirow[t]{3}{*}{1} & 0.50 & 0.05 & 1028 & 1047 \\
\hline & & & 1032 & \\
\hline & & & 2101 & \\
\hline \multirow[t]{3}{*}{2} & 1.00 & 0.10 & 1987 & 2053 \\
\hline & & & 2072 & \\
\hline & & & 18948 & \\
\hline \multirow[t]{3}{*}{3} & 10.00 & 1.00 & 18171 & 18421 \\
\hline & & & 18145 & \\
\hline & & & 49348 & \\
\hline \multirow[t]{3}{*}{4} & 25.00 & 2.50 & 50589 & 50105 \\
\hline & & & 50378 & \\
\hline & & & 101227 & \\
\hline \multirow[t]{3}{*}{5} & 50.0 & 5.00 & 101704 & 101425 \\
\hline & & & 101345 & \\
\hline & & & 160938 & \\
\hline \multirow[t]{3}{*}{6} & 80.0 & 8.00 & 161536 & 161103 \\
\hline & & & 160835 & \\
\hline & & & 202514 & \\
\hline \multirow[t]{3}{*}{7} & 100.0 & 10.00 & 202813 & 202551 \\
\hline & & & 202325 & \\
\hline & & & 244146 & \\
\hline \multirow[t]{2}{*}{8} & 120.0 & 12.00 & 240250 & 241939 \\
\hline & & & 241420 & \\
\hline
\end{tabular}
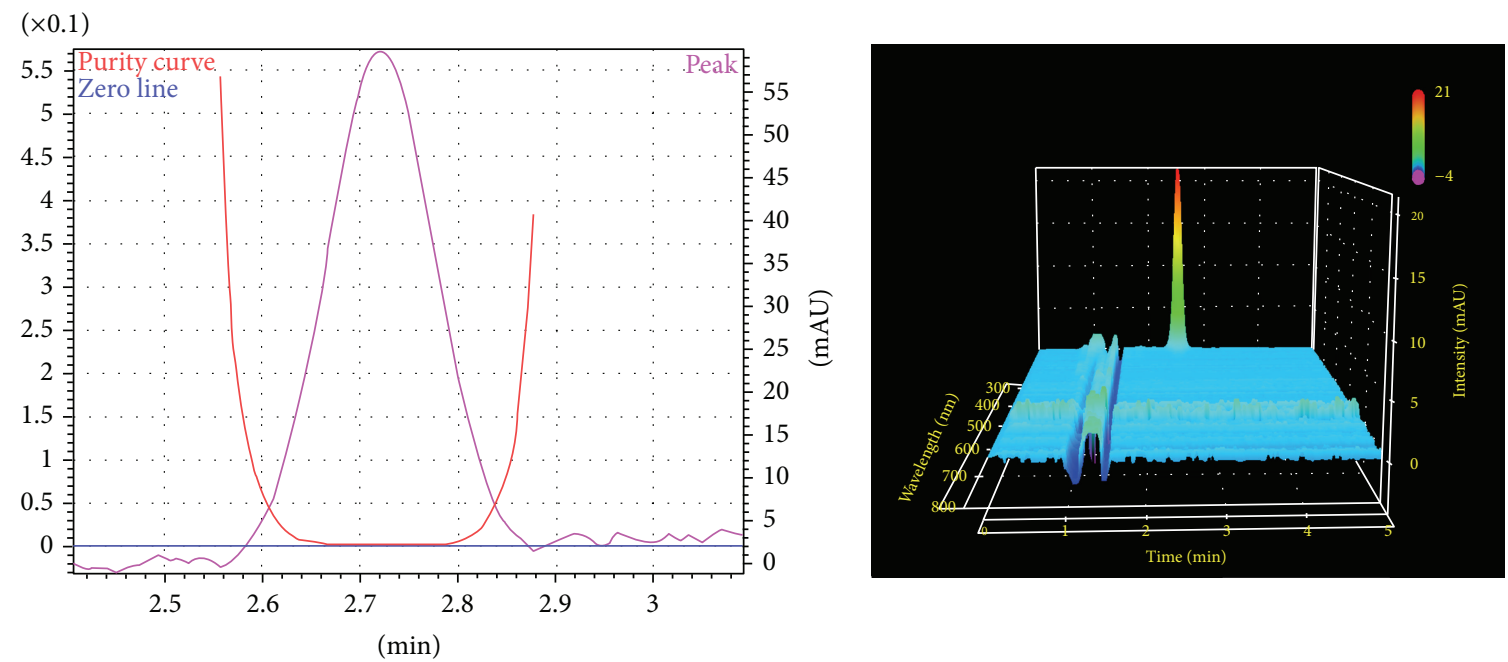

Impurity: not detected

Peak purity index: 0.9999

Single point threshold: 0.997924

Minimum peak purity index: 1975

(a)

(b)

FIGURE 3: Peak purity of dissolution assay sample of rabeprazole sodium. (a) peak purity curve (b) In 3D visualization: peak retention time (min), absorbance $(\mathrm{nm})$, and intensity (mAU) are presented in $X-, Y$-, and $Z$-axes, respectively, from Shimadzu LabSolution software. 
TABLE 3: Accuracy studies of RPS in drug-placebo solutions.

\begin{tabular}{|c|c|c|c|c|c|}
\hline Sample conc. \% & Amount added $(\mu \mathrm{g} / \mathrm{mL})$ & Peak area of sample & Amount recovered $(\mu \mathrm{g} / \mathrm{mL})$ & $\%$ Recovery & $\begin{array}{c}\text { \% Recovery } \\
(\text { mean } \pm \text { RSD })\end{array}$ \\
\hline \multirow{3}{*}{0.0} & 0.0 & 0.0 & 0.0 & 0.0 & \multirow{3}{*}{0.0} \\
\hline & 0.0 & 0.0 & 0.0 & 0.0 & \\
\hline & 0.0 & 0.0 & 0.0 & 0.0 & \\
\hline \multirow{3}{*}{50} & 5.0 & 97466 & 5.1 & 101.9 & \multirow{3}{*}{$101.7 \pm 0.4$} \\
\hline & 5.0 & 96848 & 5.0 & 101.2 & \\
\hline & 5.0 & 97472 & 5.1 & 101.9 & \\
\hline \multirow{3}{*}{100} & 10.0 & 193783 & 10.1 & 101.3 & \multirow{3}{*}{$101.4 \pm 0.2$} \\
\hline & 10.0 & 194406 & 10.1 & 101.6 & \\
\hline & 10.0 & 193829 & 10.1 & 101.3 & \\
\hline \multirow{3}{*}{120} & 12.0 & 229764 & 12.0 & 100.1 & \multirow{3}{*}{$100.0 \pm 0.1$} \\
\hline & 12.0 & 229820 & 12.0 & 100.1 & \\
\hline & 12.0 & 229235 & 12.0 & 99.9 & \\
\hline
\end{tabular}

TABLE 4: Intraday and interday precision of the method.

\begin{tabular}{lccc}
\hline Sr. number & Concentration $(\mu \mathrm{g} / \mathrm{mL})$ & \multicolumn{2}{c}{ Peak area of standard solution } \\
Interday precision \\
\hline 1 & 10 & 206799 & 210365 \\
2 & 10 & 205732 & 209625 \\
3 & 10 & 203999 & 211009 \\
4 & 10 & 202773 & 210253 \\
5 & 10 & 208159 & 209663 \\
6 & 10 & 210564 & 206186 \\
Mean & & 206338 & 209517 \\
\%RSD & & 1.4 & 0.8 \\
\hline
\end{tabular}

TABLE 5: Stability of analytical sample solution.

\begin{tabular}{lcccc}
\hline Hour & Concentration $(\mu \mathrm{g} / \mathrm{mL})$ & Room temperature $\left({ }^{\circ} \mathrm{C}\right)$ & Peak area of sample & $\begin{array}{c}\text { Difference percentage } \\
(\%) \text { from initial }\end{array}$ \\
\hline 0 & 10 & $25 \pm 2$ & 207960 & 0.0 \\
1 & 10 & $25 \pm 2$ & 205734 & 1.1 \\
2 & 10 & $25 \pm 2$ & 204729 & 1.6 \\
3 & 10 & $25 \pm 2$ & 204185 & 2.8 \\
4 & 10 & $25 \pm 2$ & 202898 & 2.4 \\
5 & 10 & $25 \pm 2$ & 200037 & 3.8 \\
6 & 10 & $25 \pm 2$ & 197381 & 5.1 \\
\hline
\end{tabular}

TABLE 6: Robustness of the method.

\begin{tabular}{|c|c|c|c|c|c|}
\hline \multirow{2}{*}{ Parameters } & \multirow{2}{*}{ Variance } & \multirow{2}{*}{ Amount added $(\mu \mathrm{g} / \mathrm{mL})$} & \multirow{2}{*}{ Retention time (min) } & \multicolumn{2}{|c|}{ Mean area of peak $\pm \% \mathrm{RSD}, n=3$} \\
\hline & & & & Standard & Sample \\
\hline \multirow{2}{*}{ Flow rate } & $0.9 \mathrm{~mL} / \mathrm{min}$ & 10 & 2.8 & $219467 \pm 0.3$ & $225203 \pm 0.4$ \\
\hline & $1.1 \mathrm{~mL} / \mathrm{min}$ & 10 & 2.2 & $184626 \pm 0.3$ & $188516 \pm 0.3$ \\
\hline \multirow{2}{*}{$\begin{array}{l}\text { Organic (\%) in } \\
\text { mobile phase }\end{array}$} & 59 & 10 & 2.7 & $207066 \pm 0.5$ & $206049 \pm 0.3$ \\
\hline & 61 & 10 & 2.5 & $203858 \pm 0.3$ & $203051 \pm 0.4$ \\
\hline \multirow{2}{*}{ Detector wavelength } & $278 \mathrm{~nm}$ & 10 & 2.7 & $199421 \pm 0.2$ & $198228 \pm 0.6$ \\
\hline & $282 \mathrm{~nm}$ & 10 & 2.7 & $213519 \pm 0.4$ & $211768 \pm 0.7$ \\
\hline
\end{tabular}


TABLE 7: Ruggedness of the method.

\begin{tabular}{lcc}
\hline Sample & Amount of standard RPS (mg) & Drug release (\%) in buffer at 20 min (mean \pm \%RSD), $n=6$ \\
\hline AcipHex 20 mg DR tablet & 20.0 & $100.1 \pm 0.1$ \\
\hline
\end{tabular}

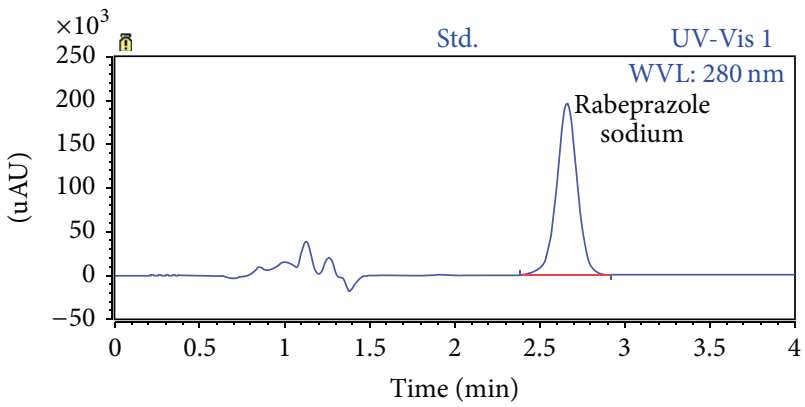

FIgURE 4: Chromatogram of rabeprazole sodium from Dionex HPLC 3000 Series.

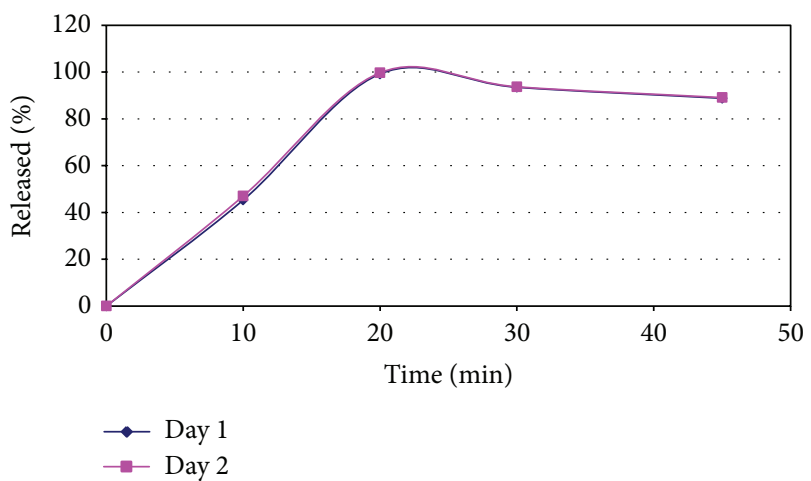

FIGURE 5: Dissolution profile of AcipHex DR tablets in tris buffer medium.

3.3. Application of the Developed Method. The validated method was used for the analysis of a commercial brand (AcipHex) of RPS delayed-release tablet formulation with dose strength $20 \mathrm{mg}$ per tablet. To achieve significant results total twenty-four numbers of tablets were analyzed in two different days (12 tablets per day) into the twelve vessels containing dissolution unit, and the sampling was done from the acid and the buffer stage according to the US FDA recommended time intervals. At acid stage, there was always $0 \%$ release of RPS. While at buffer stage, the plateau of the dissolution profile was reached within $20 \mathrm{~min}$ for both days analysis. Mean release at buffer stage of twelve tablets was found $99 \%$ with \%RSD 1.7 and 100\% with \%RSD 1.1 for day 1 and day 2 , respectively at $20 \mathrm{~min}$.

Two-days analysis results of AcipHex DR tablets also agreed with the stability nature of RPS in tris buffer. The RPS release for AcipHex was found rapid and maximum $(98-102 \%)$ at $20 \mathrm{~min}$, most of all the tablets disintegrated within $10 \mathrm{~min}$. After reaching maximum release; significant degradation was observed at $30 \mathrm{~min}$ and $45 \mathrm{~min}$ in tris buffer medium containing sensitive RPS sample (Figure 5). The mean release of RPS $(n=12)$ on day 1 , at $30 \mathrm{~min}$ and $45 \mathrm{~min}$ was found 94\% (\%RSD 2.1) and 89\% (\%RSD 1.6) and on day 2 , at $30 \mathrm{~min}$ and $45 \mathrm{~min}$ the mean release of RPS was found 93\% (\%RSD 0.9) and 87\% (\%RSD 1.1) respectively.

The US FDA guideline for dissolution testing of extended release oral dosage forms that recommends the last point should be the time point where $80 \%$ drug has dissolved [26]. Finally, during dissolution assay preparations, sample was withdrawn from buffer medium at $20 \mathrm{~min}$, while it released maximum, and after immediate dilution into methanol the assay sample was found stable up to 3 hours.

\section{Conclusion}

In recent days, more importance has been placed on dissolution testing by the pharmaceutical industry and regulatory authorities. The main objective of the proposed method was to establish a reliable procedure to analysis of RPS dissolution samples according to US FDA recommended dissolution medium. The new RP-HPLC method for quantification of RPS is simple, precise, accurate, reproducible and rapid. The developed method was validated based on ICH and USP guidelines and successfully applied to in vitro dissolution test studies of RPS. The short run time of $4 \mathrm{~min}$ of this method allows to analyze sensitive RPS samples in a short period of time, which also makes it cost-effective for the routine quality control analysis work.

\section{Acknowledgments}

The author is thankful to ACI Limited, Narayanganj, Bangladesh, for providing all kind of financial and technical facilities to conduct this study. The author also acknowledged the team members and the management.

\section{References}

[1] D. Pantoflickova, G. Dorta, M. Ravic, P. Jornod, and A. L. Blum, "Acid inhibition on the first day of dosing: comparison of four proton pump inhibitors," Alimentary Pharmacology and Therapeutics, vol. 17, no. 12, pp. 1507-1514, 2003.

[2] C. A. Desai and B. D. Samant, "Rabeprazole," Journal of Postgraduate Medicine, vol. 48, no. 1, pp. 80-81, 2002.

[3] C. V. Garcia, C. S. Paim, and M. Steppe, "New liquid chromatographic method for determination of rabeprazole sodium in coated tablets," Journal of AOAC International, vol. 87, no. 4, pp. 842-846, 2004.

[4] U. M. Karra and S. Yarkala, "A simple and validated reverse phase HPLC method for the determination of rabeprazole in pharmaceutical dosage forms," E-Journal of Chemistry, vol. 7, no. 2, pp. 569-577, 2010.

[5] R. Buchireddy, K. Mukkanti, P. Srinivasulu, and K. S. V. Srinivas, "A validated, stability-indicating, LC method for rabeprazole sodium," Chromatographia, vol. 68, no. 3-4, pp. 275-280, 2008. 
[6] P. R. Battu and M. S. Reddy, "Development and validation of RP-HPLC for the rabeprazole sodium in pharmaceutical formulations and human plasma," Asian Journal of Research in Chemistry, vol. 2, pp. 49-51, 2009.

[7] Y. S. Rhee, C. W. Park, Y. S. Shin, S. H. Kam, K. H. Lee, and E. S. Park, "Application of instrumental evaluation of color for the pre-formulation and formulation of rabeprazole," International Journal of Pharmaceutics, vol. 350, no. 1-2, pp. 122-129, 2008.

[8] V. G. Cássia, S. N. Norma, S. Martin, and E. S. S. Elfrides, "Structural elucidation of rabeprazole sodium photodegradation products," Journal of Pharmaceutical and Biomedical Analysis, vol. 46, no. 1, pp. 88-93, 2008.

[9] M. Miura, H. Tada, S. Satoh, T. Habuchi, and T. Suzuki, "Determination of rabeprazole enantiomers and their metabolites by high-performance liquid chromatography with solid-phase extraction," Journal of Pharmaceutical and Biomedical Analysis, vol. 41, no. 2, pp. 565-570, 2006.

[10] A. El-Gindy, F. El-Yazby, and M. M. Maher, "Spectrophotometric and chromatographic determination of rabeprazole in presence of its degradation products," Journal of Pharmaceutical and Biomedical Analysis, vol. 31, no. 2, pp. 229-242, 2003.

[11] H. Nakai, Y. Shimamura, T. Kanazawa, S. Yasuda, and M. Kayano, "Determination of a new $\mathrm{H}^{+}-\mathrm{K}^{+}$ATPase inhibitor (E3810) and its four metabolites in human plasma by highperformance Liquid chromatography," Journal of Chromatography B: Biomedical Applications, vol. 660, no. 1, pp. 211-220, 1994.

[12] A. A. Shirkhedkar and S. J. Surana, "Application of stabilityindicating RP-TLC densitometric determination of rabeprazole sodium in bulk drug and pharmaceutical formulation," Eurasian Journal of Analytical Chemistry, vol. 4, pp. 87-97, 2009.

[13] P. B. Raval, M. Puranik, S. J. Wadher, and P. G. Yeole, "A validated HPTLC method for determination of ondansetron in combination with omeprazole or rabeprazole in solid dosage form," Indian Journal of Pharmaceutical Sciences, vol. 70, no. 3 , pp. 386-390, 2008.

[14] B. H. Patel, B. N. Suhagia, M. M. Patel, and J. R. Patel, "HPTLC determination of rabeprazole and domperidone in capsules and its validation," Journal of Chromatographic Science, vol. 46, no. 4, pp. 304-307, 2008.

[15] N. Rahman, Z. Bano, and S. N. H. Azmi, "Quantitative analysis of rabeprazole sodium in commercial dosage forms by spectrophotometry," Chemical and Pharmaceutical Bulletin, vol. 56, no. 7, pp. 995-1001, 2008.

[16] D. Madhuri, K. B. Chandrasekhar, M. Ramakotaiah, G. Somasekhar, K. Harinadhababa, and K. R. Kumar, "Validation of spectrophotometric determination of Rabeprazole using ferric chloride $\left(\mathrm{FeCl}_{3}\right)$," International Journal of Research in Pharmaceutical Sciences, vol. 1, no. 2, pp. 209-211, 2010.

[17] M. M. Gouda, S. Somashekar, P. R. Kumar, and S. M. S. Kumar, "Physico-chemical characterization, UV spectrophotometric analytical method development and validation studies of rabeprazole sodium," Journal of Chemical and Pharmaceutical Research, vol. 2, pp. 187-192, 2010.

[18] F. Shao, J. Sun, G. Wang, H. Xie, X. Zhu, and J. Zhang, "Liquid chromatographic-mass spectrometry analysis and pharmacokinetic studies of a novel rabeprazole formulation, sterile powder for injection, in dogs and rats," Biopharmaceutics and Drug Disposition, vol. 28, no. 4, pp. 177-186, 2007.

[19] A. Radi, N. Abd El-Ghany, and T. Wahdan, "Voltammetric behaviour of rabeprazole at a glassy carbon electrode and its determination in tablet dosage form," Farmaco, vol. 59, no. 7, pp. 515-518, 2004.
[20] B. H. Patel, B. N. Suhagia, M. M. Patel, and J. R. Patel, "Highperformance liquid chromatography and thin-layer chromatography for the simultaneous quantitation of rabeprazole and mosapride in pharmaceutical products," Journal of Chromatographic Science, vol. 46, no. 1, pp. 10-14, 2008.

[21] S. S. Shweta, D. D. Nilesh, Y. J. Vijay, R. T. Santosh, and V. G. Santosh, "Spectrophotometric simultaneous determination of rabeprazole sodium and domperidone in combined tablet dosage form," Eurasian Journal of Analytical Chemistry, vol. 3, pp. 236-244, 2008.

[22] ICH, Validation of Analytical Procedures: Text and Methodology Q2 (R1), ICH, Geneva, Switzerland, 1996.

[23] The United States Pharmacopoeia, 35, NF 30, vol. 1, United States Pharmacopeial Convention, Rockville, Md, USA, 2012.

[24] U.S. Food and Drug Administration, Dissolution Methods Database, http://www.accessdata.fda.gov/scripts/cder/dissolution/dsp_searchresults_dissolutions.cfm?printall=1.

[25] Dissolution Testing of Immediate Release Solid Oral Dosage Forms, Guidance for Industry, U.S. Department of Health and Human Services, Food and Drug Administration, Center for Drug Evaluation and Research (CDER), U.S. Government Printing Office, Washington, DC, USA, 1997.

[26] Extended Release Oral Dosage Forms: Development, Evaluation, and Application of In Vitro/In Vivo Correlations, Guidance for Industry, U.S. Department of Health and Human Services, Food and Drug Administration, Center for Drug Evaluation and Research (CDER), U.S. Government Printing Office, Washington, DC, USA, 1997. 

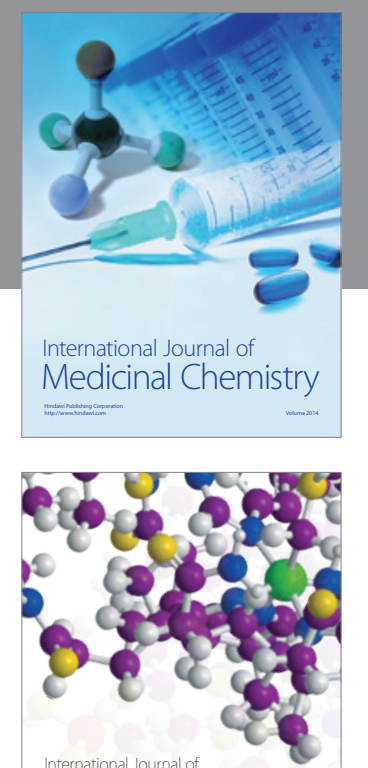

\section{Carbohydrate} Chemistry

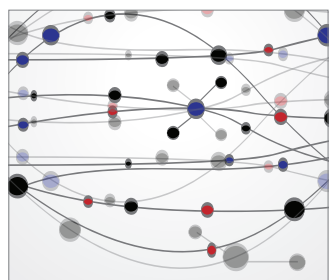

The Scientific World Journal
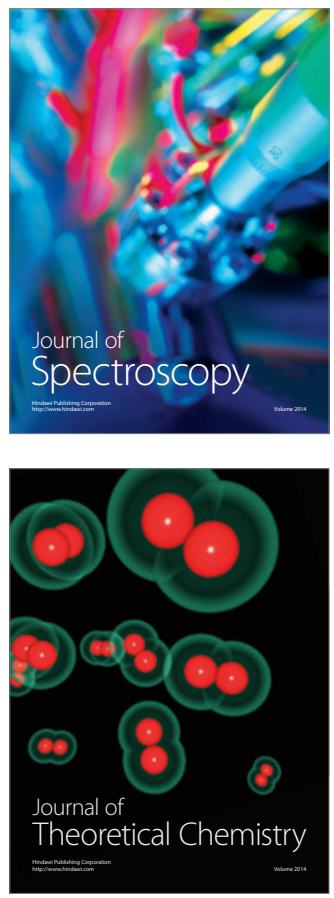
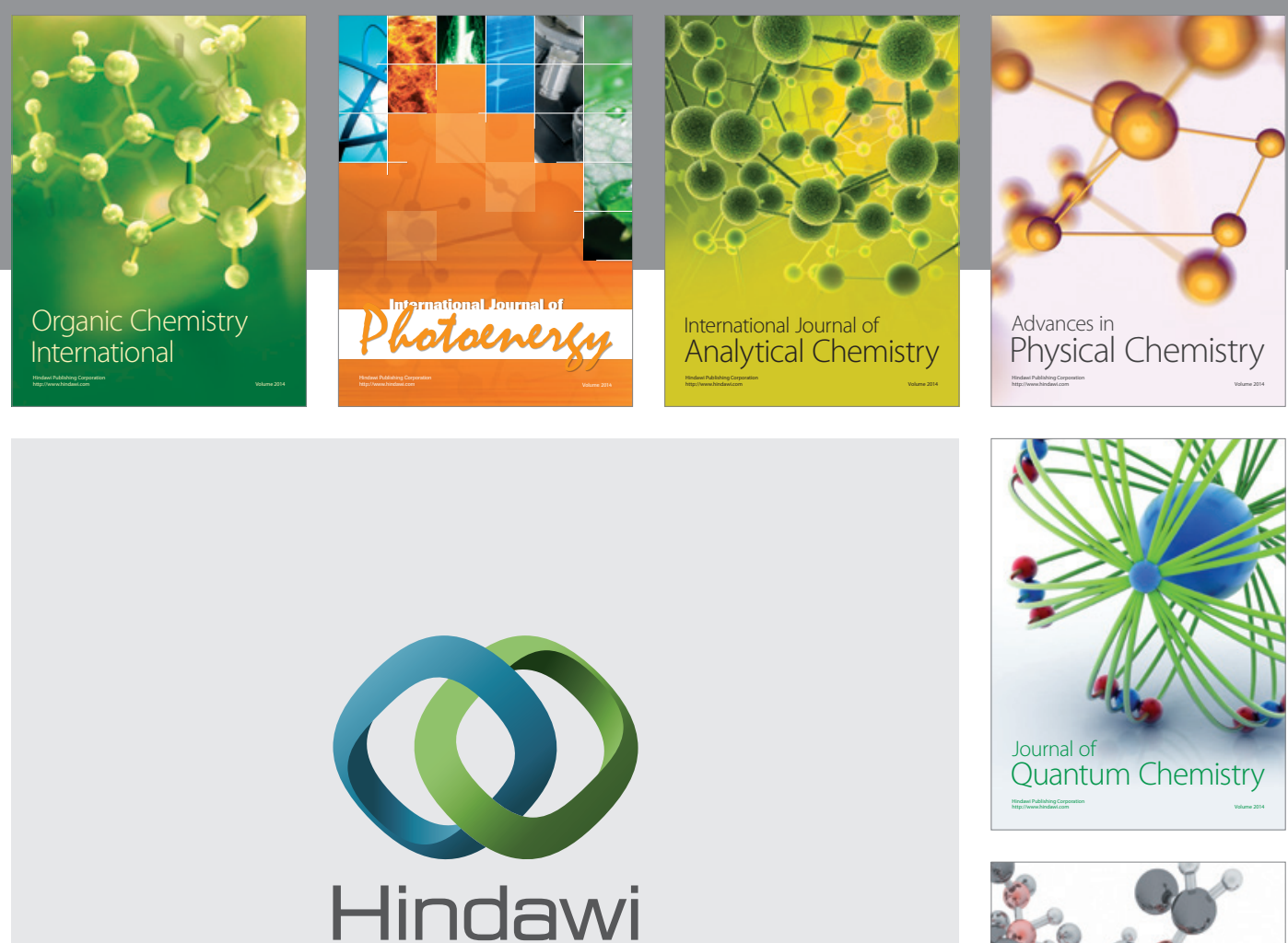

Submit your manuscripts at

http://www.hindawi.com

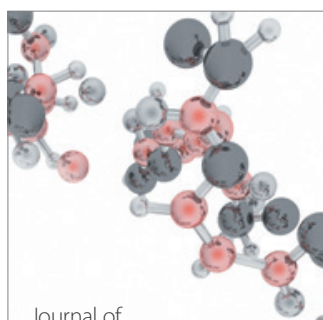

Analytical Methods

in Chemistry

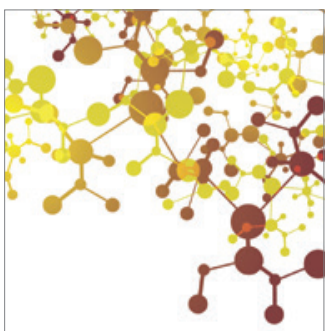

Journal of

Applied Chemistry

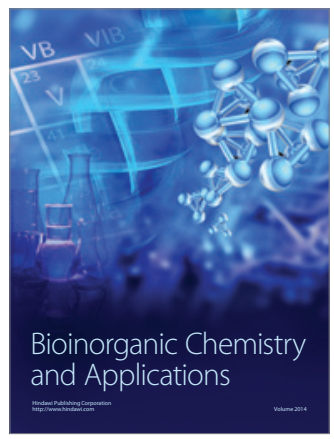

Inorganic Chemistry
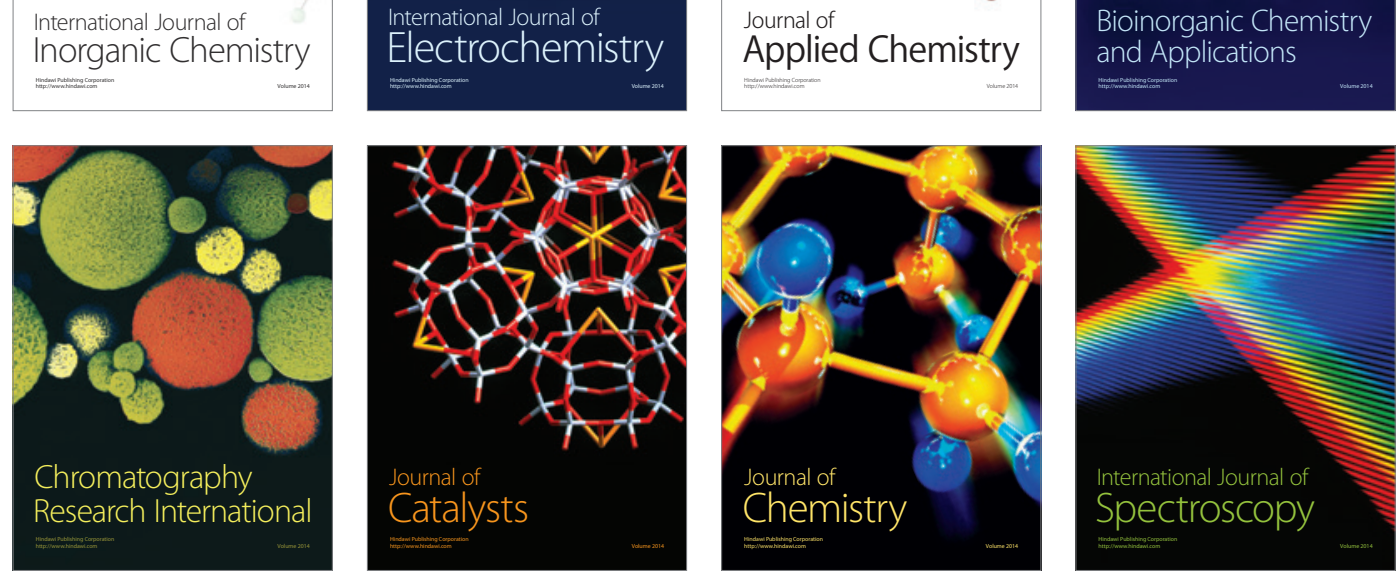